\title{
VOLUNTARY INSTRUMENTS IN THE SPHERE OF PRODUCTION IN EUROPEAN UNION LAW AND THEIR IMPORTANCE TO UKRAINE
}

\section{Kachuriner V. L.}

\section{INTRODUCTION}

Environmental protection is one of the priority areas of the European Union's activities, which defines the EU's competence in the field of environmental protection and causes the adoption of a large number of panEuropean regulations. However, despite the considerable regulatory framework, there is insufficient attention in the EU legal system to legal regulation in the field of production and systematization of legal instruments of such regulation. The development of European environmental law is characterized by the search for optimal approaches to solving complex problems of natural resource management.

In the Association Agreement between Ukraine and the European Union, Article 360-366 of Section V, Economic and Sectoral Cooperation, is devoted to the environment itself. The Parties to the Agreement cooperate on environmental issues and thus contribute to the achievement of the goals of sustainable development and the "green economy". An analysis of European Union environmental legislation is essential to further improve and improve the effectiveness of Ukraine's environmental legislation. The priority of Ukraine's cooperation with the European Union will also be of practical importance - achieving the goal of improving the level of production productivity, expanding its economic growth base and competitiveness.

\section{Environmental agreements and environmental impact assessment as voluntary instruments in the sphere of production}

Developing a comprehensive production policy is a top priority for the European Union, given that positive EU action is aimed at identifying existing specific pollutants and protecting human health and improving the environment. As O. Dubovik rightly pointed out, there are currently several "approaches" and, accordingly, areas of legal regulation at EU level regarding the impact of production on the environment. These include: a) chemicals (most often this approach is manifested in the limitation of hazardous substances), b) hazardous waste management, hazardous substances and product "circulation", d) Commission recommendations on products used for energy production, e) the introduction of eco-labels, e) agreements in the field 
of ecology, g) integrated production and product management policies, c) resource management strategy, and) standardization ${ }^{1}$. In addition, O. Dubovik notes that the legal instruments of regulation in the sphere of production include: certification, setting standards and standards, environmental expertise ${ }^{2}$. But $T$. Rednikova offers several other legal instruments in the field of production: ecodesign, creation of ecological markets for dissemination of information by means of eco-labeling and product declarations, as well as sustainable consumption (in other words, making it environmentally friendly) ${ }^{3}$.

From the point of view of O. Trush, M. Andriyenko and G. Lomovsky, the European Union has introduced a range of environmental instruments: LIFE; environmental agreements; environmental duties and taxes; support programs for non-governmental organizations active in the field of environmental protection; Integrated product policy; The European Environment Agency; Eco-labeling of products; EU Eco-Management and Environmental Audit Scheme (EMAS); Environmental Impact Assessment (EIA) for certain public and private projects; assessment of the environmental impact of the implementation of plans and programs; environmental checks; European inventory of pollutants and transfers of pollutants ${ }^{4}$.

Considering the opinions of scientists, we propose to include the following voluntary instruments in the field of production in the law of the European Union:

1) environmental agreements: improving the environmental aspects of enterprise operations and implementing sustainable production methods through the promotion of voluntary measures and environmental agreements;

2) EU environmental management and environmental audit (EMAS) system: EMAS aims at ensuring continuous improvement of the environmental performance of European organizations, as well as providing relevant information to the public and stakeholders;

3) eco-labeling, which is focused on minimizing the negative environmental impacts of the main production or resource extraction, production of the products that are reflected in the standard. The marking process is usually called certification;

1 Дубовик О. Л. Экологическое право ЕС : формирование, развитие, достижения и актуальные задачи. Право и политика. 2004. № 12. С. 63.

${ }^{2}$ Дубовик О. Л. Международное право. М., 2003. С. 497.

${ }^{3}$ Редникова Т. В. Современные тенденции развития экологической политики в области производства продукции в Европейском Союзе. Политика и общество. 2006. № 6. С. 103.

${ }^{4}$ Труш О. О., Андрієнко М. В., Ломовських Г. А. Формування та реалізація спільної екологічної політики Свропейського Союзу в умовах сучасних інтеграційних процесів. Державне управління. 2014. № 1. URL: http://www.kbuapa.kharkov.ua/e-book/db/20141/doc/4/05.pdf 
4) Impact assessment can broadly be defined as assessing (predicting) the effects of current or anticipated action and assessing the environmental impact of plans and programs.

Let us analyze each of these tools. EU environmental policy instruments in the field of production should include instruments of a voluntary nature, such as voluntary agreements and "self-commitments", which have made many strides in the field in the last decade. It is possible that voluntary agreements have the chance to make manufacturers fully responsible, since targets are set directly on the basis of industry proposals. T. Rednikova in this regard noted that it can serve as a further motivation for the industry and mobilize its resources if the compliance of the industrial enterprise with its own requirements means trust in it ${ }^{5}$. Through voluntary agreements, changes in the production process can be implemented that will enhance environmental responsibility. As an example, Denmark has taken a significant step in this direction. In December 1996, the Danish Environmental Protection Agency formulated an Intensified, Product-Oriented, Environmental Initiative, which set out the following objectives: environmental (reducing the overall environmental impact of production, circulation and disposal); business objectives (increasing competition for the Danish business community by establishing the basis for the development, production and marketing of products with improved environmental performance); goals of organization of the process (involvement of all stakeholders in the implementation of environmental and commercial goals) ${ }^{6}$. As a result of such an initiative, as pointed out by T. Rednikova ${ }^{7}$, the negative impact of the production process on the environment was reduced.

It should be noted that environmental problems are not limited to the problem of polluting emissions from manufacturing plants, but are increasingly global. That is, the focus is not so much on the production process but on the environmental impact of the entire product life cycle.

Thus, if the Commission completes the analysis of the proposed environmental agreement, it may inform the European Parliament and the Council of its assessment and give its opinion on the recognition and approval of the agreement. After considering the comments received, in particular from the European Parliament and the Council, the Commission may decide to

\footnotetext{
${ }^{5}$ Редникова Т. В. Современные тенденции развития экологической политики в области производства продукции в Европейском Союзе. Политика и общество. 2006. № 6. С. 107.

6 Intensified Product Oriented Environmental Initiative. Copenhagen: Environmental Protection Agency, Ministry of Environment, 1996. P. 13-14.

${ }^{7}$ Редникова Т. В. Формирование и реализация интегрированной политики в области производства продукции в ЕС на национальном уровне на примере Дании. Право $u$ политика. 2009. № 12. С. 2467.
} 
recognize the environmental agreement. Information on such an environmental agreement is available, for example, on the commission's website, in order to give the general public an opportunity to be aware of the proposed Agreement and to comment ${ }^{8}$. Any recommendations for environmental agreements should be published in an official journal.

It is necessary to stimulate the preparation of voluntary environmental agreements at the Union level in various sectors of environmental legislation, but first of all, taking into account the scope of production, since today the reduction of production cannot be avoided, as, as D. Meadows correctly stated $^{9}$, mankind cannot abandon the traditional approach and is steadily increasing its industrial production by consuming natural resources. As this tool may not necessarily be the most appropriate in all circumstances, it is useful to identify a limited number of environmental policy areas where environmental agreements may provide additional benefits.

In the industry of EU Member States, "voluntary initiatives" are emerging to strengthen the environmental orientation of businesses and organizations. Yes, a number of companies have developed environmental and sustainable development policy principles. The Union of Entrepreneurs of the European Union have developed codes of conduct and recommendations for their members that contain environmental policy principles. The experience of developing such codes of conduct for industrialists and entrepreneurs is useful for our country as it is important for compliance with legal environmental requirements and organization of environmental activities of industrial enterprises in Ukraine.

The European Commission, while emphasizing the benefits of continuing to use "environmental agreements" capable of providing an effective and costeffective solution to the problems, has developed key criteria to be followed when concluding them. V. Kruglov states that environmental agreements have significant potential at the local level, because they allow to take into account the specifics of industrial production and on this basis to solve environmental problems of enterprises and territories related to, for example, water quality or restoration works after object closure ${ }^{10}$.

Regarding the environmental impact assessment (Impact assessment) in a broad sense, P. Modak defines it as an assessment (prediction) of the effects

${ }^{8}$ Communication from the Commission to the European Parliament, the Council, the Economic and Social Committee and the Committee of the Regions - Environmental Agreements at Community Level - Within the Framework of the Action Plan on the Simplification and Improvement of the Regulatory Environment / COM (2002) 412 final. P. 10.

${ }^{9}$ Политология : хрестоматия / Сост. М. А. Василик, М. С. Вершинин. М. : Гардарики, 2000. C. 786.

10 Круглов В. В. Законодательство Европейского Сообщества в сфере охраны окружающей среды в промышленности. Экологическое право. 2005. № 2. С. 46. 
of current or anticipated action ${ }^{11}$. Regarding the environmental impact of the implementation of plans and programs, it is undertaken to facilitate the integration of environmental aspects in the development stages of such plans and programs. The most significant types of assessments considered are: the Environmental Impact Assessment (EIA), the Strategic Environmental Assessment (SEA) and the Sustainability Impact Assessment (SIA).

Environmental Impact Assessment aims to identify and predict the expected environmental, health and well-being impact of people from economic and other activities. The EIA methodology has gained recognition in almost all developed countries. Adopted 25 years ago, Directive 85/337 of the EIA was to make use of the experience gained, to amend the laws and policies of the European Union and the case law of the European Court of Justice. According to her, as stated by V. Shevchuk, it is obligatory for the EU member states to conduct an EIA before issuing a permit for the implementation of all major projects that could have a negative impact on the environment ${ }^{12}$. The Directive was aimed at protecting the environment and quality of life by ensuring the approximation of national legislation to EU legislation, taking into account the environmental impact assessment of public and private projects. It is a key tool for integrating environmental issues across a wide range of projects and aiming to make them environmentally sustainable. The Directive harmonizes the EIA principles by introducing minimum requirements, in particular as to the type of objects to be evaluated, the main responsibilities of the developers, the content of the assessment and the involvement of the competent authorities and the public ${ }^{13}$.

On 26 October 2012, the Commission adopted a proposal for a new directive. This proposal seeks to simplify administrative barriers, which are largely unnecessary and to facilitate the assessment of potential impacts without weakening existing environmental safeguards. The quality of the decision-making process will be enhanced, the current level of environmental protection will be improved, and businesses should enjoy a more harmonized regulatory framework. Changes are also expected in areas such as resource

${ }^{11}$ Modak P., Biswas A. K. Introduction to EIA, What is EIA in : Conducting Environmental Impact Assessment for Developing Countries. Tokyo-New York-Paris : United Nations University Press, 1999. P. 12-14.

12 Шевчук В.Я. Екологічне управління : підручник. К.: Либідь, 2004. URL: http://pidruchniki.com/14860110/ekologiya/otsinka_vplivu_navkolishnye_seredovische.

${ }_{13}$ Report from the Commission to the Council, the European Parliament, the European Economic and Social Committee and the Committee of the Regions on the application and effectiveness of the EIA Directive (Directive 85/337/EEC, as amended by Directives 97/11/EC and 2003/35/EC) / COM (2009) 378 final. URL: http://eur-lex.europa.eu/procedure/EN/198470. 
efficiency, climate change, biodiversity and emergency prevention will now be reflected in the assessment process. In the process of further refining the environmental impact assessment, a new Directive $(2014 / 52 / E C)^{14}$ was adopted, which entered into force on 15 May 2014. First, it lowers administrative burden. Secondly, it increases the level of environmental protection, with the aim of making business decisions at public and private enterprises, which are the most predictable and sustainable in the long run. More attention is being paid to areas such as resource efficiency, climate change and disaster prevention. The main changes are as follows: States now have a mandate to simplify the various environmental assessment procedures; decisions must be duly motivated, taking into account updated selection criteria; EIA reports should be made clearer to the public, especially with regard to assessing the current state of the environment and making alternative proposals on issues raised; the quality and content of the reports will be improved; the competent authorities must also prove their objectivity in order to avoid conflicts of interest.

Directive 2001/42 / EC applies to a wide range of national plans and programs (e.g. land use, transport, energy, waste, agriculture, etc.) but is not relevant to policy ${ }^{15}$. Strategic Environmental Assessment (SEA) is mandatory for plans/programs that: prepare for agriculture, forestry, fisheries, energy, industry, transport, waste/water management, telecommunications, tourism, urban and rural planning or land use and, which set the basis for future development with the consent of the projects listed in the EIA Directive. The SEA procedures are limited to the preparation of an environmental report that identifies the likely significant environmental impact and possible alternatives to the proposed plan or program. The public and environmental authorities receive information and advice on the draft plan or program and prepare environmental reports. In the case of plans and programs which may have a significant environmental impact in another Member State, the Member State in whose territory the plan or program is being developed should consult with other Member States. The purpose of this tool is to monitor significant environmental impacts of the implementation of plans/programs in order to identify unintended negative impacts and take appropriate remedial action.

${ }^{14}$ Directive 2014/52/EU of the European Parliament and of the Council of 16 April 2014 amending Directive 2011/92/EU on the assessment of the effects of certain public and private projects on the environment Text with EEA relevance. Official Journal. 2014. L 124. P. 1-18.

${ }^{15}$ Directive 2001/42/EC of the European Parliament and of the Council of 27 June 2001 on the assessment of the effects of certain plans and programmes on the environment. Official Journal. 2001. L 197. P. 32. 


\section{The legal basis for EMAS and eco-labeling in the sphere of production}

In 1993, the EU introduced a system of voluntary participation of industrial enterprises in environmental audit, which in 2001 became open to other organizational forms - administrations, consumer care institutions, etc. ${ }^{16}$. Directive 2001/42/EC on the assessment of the effects of individual plans and programs on the environment ${ }^{17}$ was adopted in order to harmonize a number of general provisions on the environmental impact assessment of development plans and programs developed in the field of agriculture, fisheries, forestry, energy, transport, water management, telecommunications, tourism, pollution control, urban and rural planning. Particular attention is paid to Directive 2001/42/EC in evaluating programs and plans capable of transboundary environmental impacts within the EU. The decision to carry out their assessment shall be taken on the basis of consultations between Member States. However, the system of environmental management, while emphasizing O. Bilyk, did not meet modern requirements, so it needed a qualitative restructuring of economic instruments of environmental regulation, the development of an effective economic mechanism of environmental protection activities, one of the main elements of which is an effective system of environmental management of industrial enterprises ${ }^{18}$.

Sponsor voluntary commitments are still rare in the environmental field. Most often, they offer financial assistance to avoid legal obligations. L. Kremer and G. Winter state that the exceptions are the obligations of the automobile industry, which reduce $\mathrm{CO} 2$ emissions in new cars, and the provisions on the use of detergents have become of some importance. Quite often, the degree of integration of organizations in Europe is insufficient to achieve a balanced, large-scale, substantial material commitment.

The legal basis for the functioning of the environmental management and audit system within the European Union is Regulation 761/2001, which establishes the conditions for the registration of objects by the organization, the requirements for environmental policies, programs and systems, the criteria for environmental audit and environmental audit procedures, as well

${ }^{16}$ Кремер Л., Винтер Г. Экологическое право и политика Европейского Союза : законодательные основы, реализация, судебная практика. Политика и общество. 2006. № 6. C. 55.

${ }^{17}$ Directive 2001/42/EC of the European Parliament and of the Council of 27 June 2001 on the assessment of the effects of certain plans and programmes on the environment. Official Journal. 2001. L 197. P. 30.

${ }^{18}$ Білик О. С. Екологічний менеджмент на промислових підприємствах України: зміст та сутність поняття. Экологический менеджмент. 2012. № 12. С. 49. 
as introduces requirements for environmental auditors and eco-auditors ${ }^{19}$. It has been adopted to assist businesses and organizations and aims to improve corporate governance, creating common technical standards for environmental policies for businesses operating in the European Union. At the same time, Regulation 761/2001 contributes to strengthening the compliance of companies with environmental requirements by Member States and the EU.

In 2009, the Council of Europe and the European Parliament adopted at first reading the decision to reform two key EU instruments in the area of sustainable consumption and production management - Ecolabel and the Environmental Management and Audit System (EMAS). Both schemes will continue to be voluntary.

Due to the multilingualism in the EU, it is necessary to develop symbols that inform the user without additional linguistic information about positive or negative qualities. No political system has so far been able to develop such a system of symbols. Eco-labeling is a voluntary program designed to motivate producers of goods and services. The goal is to promote products with reduced environmental impact (compared to other products in the same group), to make consumers more loyal to nature and European consumers, and to make them more recognizable as environmentally friendly products ${ }^{20}$. This program is the result of various national initiatives such as "Der blaue Engel" (Germany), "Milieukeur" (Netherlands) or "White Swann" (Scandinavian

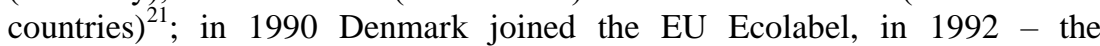
introduction of the European Flower label in Denmark ${ }^{22}$, in 1997 - Denmark joined the Scandinavian Liberty labeling system ${ }^{23}$.

Industrial products are increasingly the result of processes involving several large and small companies at the same time. Today, consumers need quality, innovative products that are environmentally friendly and of a higher quality. In this context, the isolationist competitive strategy is losing its

${ }^{19}$ Directive 2000/60/EC of the European Parliament and of the Council of 23 October 2000 establishing a framework for Community action in the field of water policy. Official Journal. 2000. L 327. P. 10.

${ }^{20}$ European Commission, 2006b. European Commission, Environment, Eco-label. URL: http://ec.europa.eu/environment/ecolabel/index_en.htm.

21 Мельник Л. Г., Дегтярьова І.Б. Європейський досвід використання економікоправових інструментів забезпечення сталого розвитку. Механізм регулювання економіки. Суми. 2012. № 1. С. 20.

${ }^{22}$ Eritja Mar Campins. European Community Eco-Labeling Scheme / Ed. by Prof. Richard. Macrory. Reflections on 30 Years of EU Environmental Law. Groningen: Europa Law Publishing, 2006. P. 109-128.

${ }^{23}$ Редникова Т. В. Формирование и реализация интегрированной политики в области производства продукции в ЕС на национальном уровне на примере Дании. Право $u$ политика. 2009. № 12. С. 2466. 
relevance. Companies and organizations are forced to work together to be able to maneuver revenues from different sources, diversify and create quality products and services. Systematic quality management is one of the important innovations of the 21st century. Quality is a concept because it combines accurate approaches, pricing aspects, meeting needs and informing consumers.

An innovative strategy to ensure the harmonization of society and the environment envisages the improvement of standardization and certification systems, their harmonization with the requirements of European legislation and regulations. According to L. Melnik, the production of environmental goods and services is a highly profitable area of economic activity, forming production that is much more gentle to the environment. Indicators of ecological excellence of products for the future should take into account packaging, which can characterize eco-degradation in the previous stages of packaging production ${ }^{24}$, where the author does not specify the meaning and function of eco-labeling.

P. Skripchuk concludes that greening the economy with the help of existing economic instruments of environmental policy on the information system of the economic sphere does not include labeling of goods, including environmental as informing the population about possible environmental damage and insufficient use of certification of quality management systems by (ISO 9000), Environmental Management Systems (ISO 14000), Life Safety (OHSAS 18001), Risk Analysis and Critical Control Point, Environmental Audit Procedures in (ISO 19011), environmental certification and many products especially food groups ${ }^{25}$.

The overall purpose of eco-labeling is to convey to consumers the information on the environmental impact of products and, on the contrary, the environment on products throughout their life cycle. One of the benefits of eco-labeled products is that they are thus identified, collected and recycled. The environmental benefits of an eco-friendly economy in many countries are well-researched and best proven in Germany (activities of associations, recyclers and recyclers, life cycle analysis of packaging or packaging, responsibility for collection of packaging in the middle of an association, etc.). packaging and packaging actually rotate into one corporation (for example, in Germany, DSD - an association of collection, processing and packaging companies that have the green marking of the "Green Dot". Other

${ }^{24}$ Мельник Л. Г. Екологічна економіка : Підручник. Суми : Університетська книга, 2002. C. 140.

25 Скрипчук П. М. Екологічне маркування: інноваційні та організаційні аспекти. Механізм регулювання економіки. № 1. 2007. С. 104-105. 
sources indicate high levels of management and environmental benefits to EU countries of using secondary packaging materials ${ }^{26}$.

An interesting report by Professor Mar Cainpins from the University of Barcelona on eco-labeling issues. This topic is especially important for the protection of consumer rights and is of interest in the field of UkrainianEuropean export-import operations. It has been noted that eco-labeling is becoming more and more important, and this is reflected in various EU programs, for example, Euro-Flower, approved by EU Decree 1980/2000 ${ }^{27}$. This program is one of the most extensive schemes in the field of legal regulation. However, there are many different kinds of endeavors that characterize different systems from different sides in different spheres, including deviations from common approaches. A key change for the EU is to address the problem of determining the place for the EU member state and thereby mediating the EU eco-labeling system and avoiding that systems that deviate from the single rule may cause barriers to the EU's internal market to increase, as well as in North-South relations. In conclusion, prof. M. Campins concluded that for successful influence on the market it is necessary to involve the society in this problem, consistency with the international character and influence of trade on developing countries ${ }^{28}$.

The voluntary nature of the Ecolabel scheme means that it does not create a barrier to market and trade, but rather gives manufacturers a competitive advantage. The Ecolabel criteria are not based on one factor, use different studies, analyze the impact of products or services on the environment throughout its life cycle, from raw material production to production, distribution and disposal. In other words, the Ecolabel European Union logo helps manufacturers and suppliers of goods and services to be recognized for high standards.

Ecolabel is part of a broader Action Plan on Sustainable Consumption and Production and Sustainable Industrial Policy, adopted by the Commission in 2008, which contains a number of key recommendations for the development and implementation of a pan-European criterion for environmentally responsible public procurement. The process of developing such a criterion at the pan-European level should take into account all existing developments in establishing an environmental criterion within the framework of sustainable production and consumption, based on the life cycle of the product or service. Examples of potential sources of such a criterion are: Energy Star energy efficiency requirements for office equipment, environmental performance

\footnotetext{
${ }^{26}$ Web-site Consumers Internationals. URL: www.consumersinter national.org/word

${ }^{27}$ Regulation (EC) № 1980/2000 of the European Parliament and of the Council of 17 July 2000 on a revised Community eco-label award scheme. Official Journal. 2000. L 237. P. 1-12.

28 Дубовик О. Л. Экологическое право ЕС : формирование, развитие, достижения и актуальные задачи. Право и политика. 2004. № 12. С. 62.
} 
criteria that will be developed in the course of implementing measures under, for example, the provisions of the Directive on the promotion of environmentally friendly and energy efficient vehicles ${ }^{29}$.

The basic principles of eco-certification are: control of the production process, not the final product; field-to-counter control, ie all stages from creation to sale to the final consumer (production, processing, sale, including importers and exporters); independence and impartiality of the certification body. Enterprises, ie manufacturers, processors, sellers, importers and exporters wishing to label their products as "environmentally friendly", "organic", "eco", "bio", etc., must undergo annual inspection and certification. The revised Ecolabel scheme simplifies the requirements for participants and focuses more on products and services that have the most significant environmental impact. During the revision of the Ecolabel provisions, the amount of the mandatory contributions was also reduced. At the end of 2009, almost 20,000 goods and services manufactured and provided in the EU were awarded the Ecolabel $\log _{0}{ }^{30}$. T. Rednikova cites such an example when, in the late 1980s, Denmark's environmental policy shifted to creating environmentally friendly "clean" production technologies. The focus was on conducting experiments to identify environmental problems in various industries and to develop demonstration projects for technical solutions to these problems within individual industrial enterprises. The disadvantage of such a program was to focus on the production process instead of exploring the entire product life cycle. Subsequently, the country paid attention to environmental management and cooperation projects between different enterprises and municipal authorities in the field of environmental protection - introduced environmental labeling of products, i.e. production and turnover issues are introduced into the common understanding of clean technologies. The introduction of clean production processes at industrial plants leads to a reduction of environmental pollution and reveals the link between environmental certification and environmental pollution control. As M. Andersen rightly pointed out, flexible environmental policies should encourage industry to introduce new forms of production and create products that are more environmentally friendly and environmentally friendly ${ }^{31}$.

${ }^{29}$ Directive 2009/33/EC of the European Parliament and of the Council of 23 April 2009 on the promotion of clean and energy-efficient road transport vehicles (Text with EEA relevance). Official Journal. 2009. L 120. P. 5.

${ }^{30}$ Directive 2009/125/EC of the European Parliament and of the Council of 21 October 2009 establishing a framework for the setting of ecodesign requirements for energy-related products. Official Journal. 2009. L 285. P. 10.

${ }^{31}$ Andersen M.S., Jorgensen U. Evaluation of Cleaner Technology Programme 1987-1992 : Results, Diffusion and Future Activities. Copenhagen : Environmental Review, 1995. № 14. 
The major changes in the EMAS scheme concerned the needs of small and medium-sized enterprises ${ }^{32}$. Innovations aimed at adopting a sectoral approach to implementing best practices in environmental management, extending EMAS beyond EU countries, and increasing monitoring of environmental compliance and developing environmental reporting systems.

The drafters believe that this should increase the number of companies participating in the Ecolabel and EMAS programs, as well as reduce the administrative pressure and costs of EU small and medium-sized enterprises ${ }^{33}$. An organization can be represented in this system or by one enterprise, or by several or even all enterprises. It has defined environmental policy and has committed itself to adhere to the relevant regulations to improve its environmental performance. The company controls the consumption of water, energy and emissions. The organization establishes a program to achieve its environmental policy goals and subject itself to internal and external audit to monitor compliance with environmental legal requirements. At the end of the progress or desired progress, this message is also checked. As a reward, an organization may indicate its affiliation with the Environmental Management and Environmental Audit system in business papers and documents, but not on products, packaging or product advertising.

For Ukraine the formation of an integrated system of environmental management in industrial enterprises is an effective tool for complex solution of the task of ensuring the quality of products, environmental protection, professional safety of production and responsibility of the enterprise to society and promoting the integration of Ukraine into the world community. The current ecological situation and trends of its change are largely determined by industrial production and economic activity in general.

Ukraine has officially joined the international community in the field of implementation and development of environmental management ${ }^{34}$. The quality of products or services is one of the most important factors in the success of any production activity. It is a set of properties and characteristics of products or services that give them the ability to meet the stipulated or foreseen needs of a modern person. O. Bilyk emphasizes that nowadays the demands of the consumer for the quality of products have considerably

32 Бут Ю.С. Управління процесами використання природних ресурсів в країнах Європейського Союзу: екологічний аспект. Виртуальная библиографическая справка. Объединенная справочная служба библиотек Украины. URL: http://www.nbuv.gov.ua/ e-journals/PSPE/2011_2/But_211.htm

${ }^{33}$ From Conflict to Peacebuilding: The Role of Natural Resources and the Environment, UNEP 2009. URL: http://www.unep.org/pdf/pcdmb_policy_01.pdf.

34 Потай О.А. Формування інтегрованої системи екологічного менеджменту промислових підприємств. Науковий вісник НЛГУ. 2009. Вип. 19.9. С. 213. 
increased all over the world, which is accompanied by the need for its constant improvement and makes it possible to achieve and maintain effective economic activity ${ }^{35}$. At the same time, requirements for the environment of the production itself, its safety for the environment, workers and society are increasing. According to this system of management of industrial enterprises are increasingly developed in integrated forms, which allows to take into account and harmoniously combine different aspects of production activity. EMAS system is not aimed at expanding economic responsibility and limiting the will of enterprises ${ }^{36}$. That is, enterprises are creating such economic incentives that encourage them to voluntarily adopt official directives in the field of environmental management. Today Ukrainian enterprises are experiencing a deep crisis, which is caused by certain objective and subjective reasons. Objective reasons are the environmental factors of the company. Subjective reasons are internal factors related to the orientation of the company, the management system, the system of supply, production and sales, organizational culture of the company, etc. In this case, one should not forget that, as V. Akulenko notes, the most important component of economic security is the human factor ${ }^{37}$.

Recommendation and eco-audit system is open to any organization that pays attention to improving the quality of its own environmental activities, regardless of ownership. The European Union also promotes such activities not only at large enterprises but also at medium and small firms, but the decision to extend the EU recommendation and eco-audit system to these categories of organizations is taken by the Member State. The need to study such issues as environmental management of production processes becomes relevant in the context of investing environmental policy programs and management in the field of environmental safety of enterprises, because stable functioning, growth of economic potential of any enterprise in terms of market relations largely depend on the availability of a reliable system environmental safety. The use of environmental management systems provides businesses with certain advantages, which include systematic reduction of negative environmental impact; systematic reduction of production and operating costs; reducing environmental payments and more

${ }^{35}$ Білик О. С. Екологічний менеджмент на промислових підприємствах України: зміст та сутність поняття. Экологический менеджмент. 2012. № 12. С. 52-53.

36 Декалюк О. В., Стасюк I. В. Впровадження екологічного менеджменту та аудиту для забезпечення екологічної безпеки підприємства. Вісник Хмельницького національного університету. 2010. № 2. Т. 1. С. 242.

37 Акуленко В. Л., Мамчук І. В. Екологічний менеджмент в контексті забезпечення екологічної безпеки підприємства. Вісник Хмельнищького національного університету. 2009. № 5. T. 1. C. 26. 
effectively complying with EU environmental legislation. Additional benefits include reducing the risk of accidents and the magnitude of their consequences; improving the competitiveness of the enterprise in the domestic and foreign markets, the possibility of developing new markets; gaining a positive image of the enterprise, improving relations with consumers, partners, investors, government bodies, and the public.

\section{CONCLUSIONS}

The measures currently being taken in the EU are currently insufficient to address the root causes of unsustainable consumption, as they are mainly aimed at mitigating its effects, and their participation is largely voluntary.

The overriding objective of voluntary instruments is to strengthen environmental responsibility through the reproduction of certain tools and procedures in EU secondary legislation, using industry proposals. Such instruments include voluntary agreements or initiatives, the eco-labeling system, the EU eco-management and environmental audit system, the environmental impact assessment and the environmental impact of the implementation of plans and programs.

Voluntary instruments use the principle of sustainable development as a dominant idea and at the same time reinforce the priority of industrial activity. It would be advisable to expand the scope of such instruments within the framework of horizontal environmental legislation, as well as to enhance the development of environmental reporting systems and environmental management of production processes, which will contribute to the establishment of a reliable system of environmental safety, health and wellbeing of people.

\section{SUMMARY}

The article deals with the analysis of voluntary instruments in the sphere of production. It includes voluntary agreements or initiatives that will enhance environmental responsibility; eco-labeling; the EU environmental management and environmental audit system; environmental impact assessment and environmental impact assessment of plans and programs. The author emphasizes that in order to better achieve environmental goals in the production sector, it is necessary not only to reproduce voluntary instruments in the secondary legislation of the European Union, but also to motivate producers to be responsible by using their proposals in industry.

The advantage of all these activities is the constant focus of public attention on the issue of interaction between production and the environment. These measures affect not only the establishment of product design in a more environmentally friendly way, but also the process of production development 
by introducing environmentally significant changes into product development, which is now a priority for the manufacturer.

Voluntary instruments use the principle of sustainable development as a dominant idea and at the same time reinforce the priority of industrial activity. For Ukraine, it would be advisable to expand the scope of such instruments within the framework of environmental legislation, as well as to enhance the development of environmental reporting and environmental management of production processes, which will contribute to the establishment of a reliable system of environmental safety, health and well-being of people.

\section{REFERENCES}

1. Акуленко В.Л., Мамчук І.В. Екологічний менеджмент в контексті забезпечення екологічної безпеки підприємства. Вісник Хмельницького національного університету. 2009. № 5. Т. 1. С. 21-26.

2. Білик О.С. Екологічний менеджмент на промислових підприємствах України: зміст та сутність поняття. Экологический менеджмент. 2012. № 12. С. 49-64.

3. Бут Ю.С. Управління процесами використання природних ресурсів в країнах Європейського Союзу : екологічний аспект. Виртуальная библиографическая справка. Объединенная справочная служба библиотек Украинь. URL: http://www.nbuv.gov.ua/ejournals/PSPE/2011_2/But_211.htm

4. Декалюк О.В., Стасюк I.В. Впровадження екологічного менеджменту та аудиту для забезпечення екологічної безпеки підприємства. Вісник Хмельнищького національного університету. 2010. № 2. T. 1. C. 235-242.

5. Дубовик О.Л. Международное право. М., 2003. 584 с.

6. Дубовик О.Л. Экологическое право ЕС : формирование, развитие, достижения и актуальные задачи. Право и политика. 2004. № 12. C. 58-67.

7. Кремер Л., Винтер Г. Экологическое право и политика Европейского Союза : законодательные основы, реализация, судебная практика. Политика и общество. 2006. № 6. С. 26-83.

8. Круглов В.В. Законодательство Европейского Сообщества в сфере охраны окружающей среды в промышленности. Экологическое право. 2005. № 2. С. 42-46.

9. Мельник Л.Г. Екологічна економіка : Підручник. Суми : Університетська книга, 2002. 346 с.

10. Мельник Л.Г., Дегтярьова І.Б. Свропейський досвід використання економіко-правових інструментів забезпечення сталого розвитку. Механізм регулювання економіки. Суми. 2012. № 1. С. 13-24. 
11. Политология : хрестоматия / Сост. М.А. Василик, М.С. Вершинин. М. : Гардарики, 2000. 843 с.

12. Потай О.А. Формування інтегрованої системи екологічного менеджменту промислових підприємств. Науковий вісник НЛГУ. 2009. Вип. 19.9. С. 212-216.

13. Редникова Т.В. Современные тенденции развития экологической политики в области производства продукции в Европейском Союзе. Политика и общество. 2006. № 6. С. 102-107.

14. Редникова Т.В. Формирование и реализация интегрированной политики в области производства продукции в ЕС на национальном уровне на примере Дании. Право и политика. 2009. № 12. С. 2465-2472.

15. Скрипчук П.М. Екологічне маркування: інноваційні та організаційні аспекти. Механізм регулювання економіки. № 1. 2007. C. 104-115.

16. Труш О.О., Андрієнко М.В., Ломовських Г.А. Формування та реалізація спільної екологічної політики Європейського Союзу в умовах сучасних інтеграційних процесів. Державне управління. 2014. № 1. URL: http://www.kbuapa.kharkov.ua/e-book/db/2014-1/doc/4/05.pdf

17. Шевчук В.Я. Екологічне управління : підручник. К. : Либідь, 2004. URL: http://pidruchniki.com/14860110/ekologiya/otsinka_vplivu_ navkolishnye_seredovische.

18. Andersen M.S., Jorgensen U. Evaluation of Cleaner Technology Programme 1987-1992 : Results, Diffusion and Future Activities. Copenhagen : Environmental Review, 1995. № 14.

19. Communication from the Commission to the European Parliament, the Council, the Economic and Social Committee and the Committee of the Regions - Environmental Agreements at Community Level - Within the Framework of the Action Plan on the Simplification and Improvement of the Regulatory Environment / COM (2002) 412 final. 14 p.

20. Directive 2000/60/EC of the European Parliament and of the Council of 23 October 2000 establishing a framework for Community action in the field of water policy. Official Journal. 2000. L 327. P. 1-73.

21. Directive 2001/42/EC of the European Parliament and of the Council of 27 June 2001 on the assessment of the effects of certain plans and programmes on the environment. Official Journal. 2001. L 197. P. 30-37.

22. Directive 2009/125/EC of the European Parliament and of the Council of 21 October 2009 establishing a framework for the setting of ecodesign requirements for energy-related products. Official Journal. 2009. L 285. P. 10.

23. Directive 2009/33/EC of the European Parliament and of the Council of 23 April 2009 on the promotion of clean and energy-efficient road transport vehicles (Text with EEA relevance). Official Journal. 2009. L 120. P. 5-12. 
24. Directive 2014/52/EU of the European Parliament and of the Council of 16 April 2014 amending Directive 2011/92/EU on the assessment of the effects of certain public and private projects on the environment Text with EEA relevance. Official Journal. 2014. L 124. P. 1-18.

25. Eritja Mar Campins. European Community Eco-Labeling Scheme / Ed. by Prof. Richard. Macrory. Reflections on 30 Years of EU Environmental Law. Groningen : Europa Law Publishing, 2006. P. 109-128.

26. European Commission, 2006b. European Commission, Environment, Eco-label. URL: http://ec.europa.eu/environment/ecolabel/index_en.htm.

27. From Conflict to Peacebuilding : The Role of Natural Resources and the Environment, UNEP 2009. URL: http://www.unep.org/pdf/pcdmb_ policy_01.pdf.

28. Intensified Product Oriented Environmental Initiative. Copenhagen : Environmental Protection Agency, Ministry of Environment, 1996. P. 13-14.

29. Modak P., Biswas A.K. Introduction to EIA, What is EIA in : Conducting Environmental Impact Assessment for Developing Countries. Tokyo-New York-Paris : United Nations University Press, 1999. P. 12-14.

30. Regulation (EC) № 1980/2000 of the European Parliament and of the Council of 17 July 2000 on a revised Community eco-label award scheme. Official Journal. 2000. L 237. P. 1-12.

31. Report from the Commission to the Council, the European Parliament, the European Economic and Social Committee and the Committee of the Regions on the application and effectiveness of the EIA Directive (Directive 85/337/EEC, as amended by Directives 97/11/EC and 2003/35/EC) / COM (2009) 378 final. URL: http://eur-lex.europa.eu/procedure/EN/198470.

32. Web-site Consumers Internationals. URL: www.consumersinter national.org/word

\section{Information about the author: Kachuriner V. L.,} $\mathrm{PhD}$, Associate Professor at the Department of State Law Disciplines, International Humanitarian University 33, Fontanska Road str., Odessa, 65009, Ukraine 